\title{
The Impact of Water on Ru-Catalyzed Olefin Metathesis: Potent Deac- tivating Effects Even at Low Water Concentrations
}

\author{
Christian O. Blanco, ${ }^{a}$ Joshua Sims, ${ }^{b}$ Daniel L. Nascimento, ${ }^{a}$ Alexandre Y. Goudreault, ${ }^{a}$ Stephan N. Stein- \\ mann, ${ }^{b}$ Carine Michel, ${ }^{* b}$ and Deryn E. Fogg $* a, c$ \\ ${ }^{a}$ Center for Catalysis Research \& Innovation, and Department of Chemistry and Biomolecular Sciences, University of Ot- \\ tawa, ON, Canada, K1N 6N57. ${ }^{b}$ Univ. Lyon, ENS de Lyon, CNRS UMR 5182, Université Claude Bernard Lyon 1, Laboratorie de \\ Chimie, F-69342 Lyon, France. 'Department of Chemistry, University of Bergen, Allégaten 41, N-5007 Bergen, Norway
}

Supporting Information Placeholder

ABSTRACT: Ruthenium catalysts for olefin metathesis are widely viewed as water-tolerant. Evidence is presented, however, that even low concentrations of water cause catalyst decomposition, severely degrading yields. Of 11 catalysts studied, fast-initiating examples (e.g., the Grela catalyst $\mathrm{RuCl}_{2}\left(\mathrm{H}_{2} \mathrm{IMes}\right)\left(=\mathrm{CHC}_{6} \mathrm{H}_{4}-2-\mathrm{O}^{i} \mathrm{Pr}-5-\mathrm{NO}_{2}\right)$ were most affected. Highest water-tolerance was exhibited by slowly-initiating iodide and cyclic (alkyl)(amino)carbene derivatives. Computational investigations indicated that hydrogen-bonding of water to substrate can also play a role, by retarding cyclization relative to decomposition. These results have important implications for olefin metathesis in organic media, where water is a ubiquitous contaminant, and for aqueous metathesis, which currently requires superstoichiometric "catalyst" for demanding reactions.

Keywords olefin metathesis, catalyst decomposition, macrocycle, conformation, water, aqueous metathesis, chemical biology, Z-selective

Olefin metathesis has been widely embraced for its versatility in the catalytic assembly of carbon-carbon bonds. ${ }^{1,2}$ The demand for catalysts that integrate high activity with robustness has intensified with a recent explosion in applications in chemical biology, ${ }^{3-5 a}$ materials science, ${ }^{6}$ and chemical manufacturing. ${ }^{7}$ Tolerance for water is critical in many contexts, most prominently olefin metathesis in water-rich environments. Successes in aqueous metathesis of model substrates with ruthenium catalysts $^{5}$ (see, e.g., Chart 1 ) have been leveraged to advance metathetical modification of proteins, ${ }^{3}$ peptides, ${ }^{8}$ and DNA, ${ }^{4 b, 9}$ and to develop water-soluble materials for drug delivery and other applications. ${ }^{6 a-e, 10,11}$

These applications place extreme demands on the watertolerance of the catalysts. Decomposition by water is increasingly identified as an obstacle to olefin metathesis in chemical biology ${ }^{3,5 a}$ (where Isenegger and Davis describe bioconjugation as a race between metathesis and decomposition $)^{3 a}$ and biomaterials applications. ${ }^{6 a-e, 10-12}$ The catalyst loadings required are routinely orders of magnitude above those in organic media: in highly demanding contexts such as protein modification, the $\mathrm{Ru}$ reagent must be used in significant stoichiometric excess. $^{13}$ An anticipated, undesirable consequence is accelerated bimolecular decomposition of the active species, ${ }^{14}$ and associated side-reactions. Decomposed catalyst is believed to trigger both DNA degradation ${ }^{9,15}$ and $\mathrm{C}=\mathrm{C}$ migration. ${ }^{16}$

Chart 1. Olefin Metathesis Catalysts Discussed 

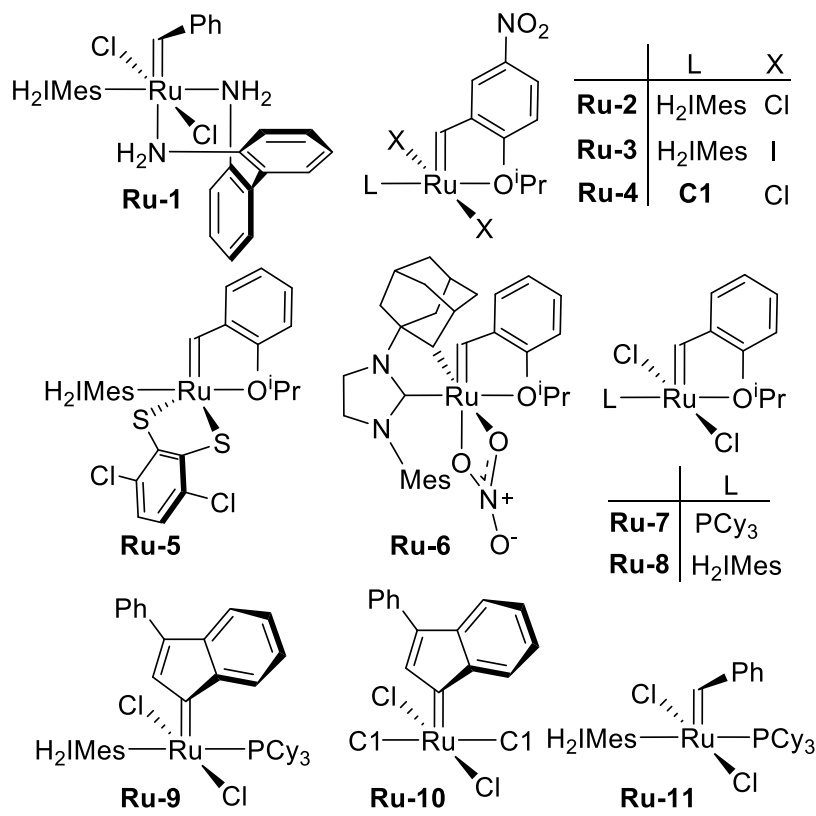

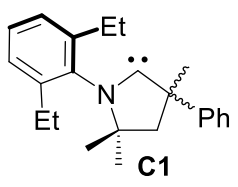

Given that the problems of water co-solvent are only beginning to be widely recognized, $, 35 a, 17,18$ it is unsurprising that challenges arising from low levels of water have not yet been considered. Here we demonstrate that even $0.1-1 \% \mathrm{v} / \mathrm{v}$ water ${ }^{19}$ can severely limit the productivity of leading NHC and CAAC ruthenium catalysts. We also identify catalyst features that maximize water-tolerance, a finding that offers new opportunities in organic synthesis, and in broader contexts in which water is an essential co-solvent.

RCM macrocyclization (mRCM) represents a methodology of major current interest for the production of antiviral therapeutics. ${ }^{7,20}$ The first indication that even low concentrations of water might impede mRCM emerged in reactions involving the dianiline catalyst Ru-1 (Chart 1). In our hands, Ru-1 was exceptionally efficient, ${ }^{21}$ outperforming even the leading nitro-Grela catalyst Ru-2 in $\mathrm{mRCM}$ of challenging, highly flexible substrates bearing multiple polar sites. Synthetic collaborators, however, observed variable performance. We speculated that the discrepancy might arise from the established ${ }^{21}$ hydrogen-bonding capacity of Ru-1. Sensitivity to water would have gone unobserved in our original work because rigorously dry ${ }^{22}$ solvents were used, a standard protocol in organometallic chemistry. In broader synthetic practice, water is a ubiquitous, little-regarded contaminant. It thus seemed plausible that water-induced decomposition might contribute to the inconsistent performance of Ru1.
To probe this point, we examined the impact of water on mRCM of 1 (Figure 1a, dotted-fill). ${ }^{23}$ This reaction affords the olfactory lactone $\mathbf{2}$ via a concentration-dependent ring-chain equilibrium. ${ }^{24} \mathrm{High}$ dilutions are essential to favour the cyclic product, as with any conformationally flexible diene. ${ }^{24,25}$ For 1 , in which the ester functionality confers the sole conformational bias toward cyclization, ${ }^{26}$ a diene concentration of $\leq 5 \mathrm{mM}$ is required. ${ }^{24}$ At catalyst loadings of $0.05 \mathrm{~mol} \%$, this translates into 2.5 $\mu \mathrm{M}$ Ru: even low concentrations of water are thus stoichiometrically significant.

In dry toluene, mRCM of 1 reached $83 \%$ yield within 0.5 $\mathrm{h}$ at RT (Figure 1a). Addition of $0.01 \%$ water - that is, 100 ppm by volume - caused a ca. $60 \%$ drop in yield. At higher proportions of water ( 0.1 or $1 \% \mathrm{v} / \mathrm{v}), \mathrm{mRCM}$ failed, signifying near-complete catalyst decomposition.

As shown in Figure $1 \mathrm{~b}$, the Grela catalyst Ru-2 is decomposed to a lesser extent, affording $30 \% \mathrm{mRCM}$ in the presence of $0.1 \% \mathrm{v} / \mathrm{v}$ water (vs $87 \% \mathrm{mRCM}$ in dry toluene). ${ }^{27}$ More robust is the iodide analogue Ru-3. Water somewhat unexpectedly - is emerging as a much more aggressive agent than $\mathrm{O}_{2}$ in $\mathrm{Ru}$-catalyzed olefin metathe$\mathrm{sis}^{28}$ and this higher water-tolerance is thus presumed to be key to the strong performance of Ru-3 in aerobic metathesis. ${ }^{29}$ One probable contributor to improved tolerance is the limited capacity of Ru-3 to enter into hydrogen-bonding interactions with water. $\mathrm{ROH}$... $\mathrm{Cl}-\mathrm{Ru}$ interactions have been reported for related metathesis catalysts, ${ }^{30,31}$ and the higher water-sensitivity of Ru-1 vs Ru$\mathbf{2}$ is consistent with stronger $\mathrm{H}$-bonding to a dangling $\mathrm{NH}_{2}$ functionality.

To assess the potential impact of water on $E / Z$ selectivity, two Z-selective catalysts (Ru-6, Ru-5) were also examined. Their lower reactivity necessitated use of elevated temperatures $\left(60{ }^{\circ} \mathrm{C}\right)$ and higher catalyst loadings. For Ru-5, only $17 \%$ mRCM was observed even with 5 mol\% catalyst: added water had no impact, probably because only a small proportion of catalyst had initiated. ${ }^{32}$ Ru- 6 afforded 64\% mRCM in the anhydrous reaction $(0.5 \mathrm{~mol} \%$ $\mathrm{Ru})$, and $25 \%$ in the presence of water. Of note, water had negligible impact on Z-selectivity (Ru-6, 85\%; Ru-5, $70 \%)$. We infer that decomposed catalyst does not promote $E / Z$ isomerization, at least for Ru-6. 


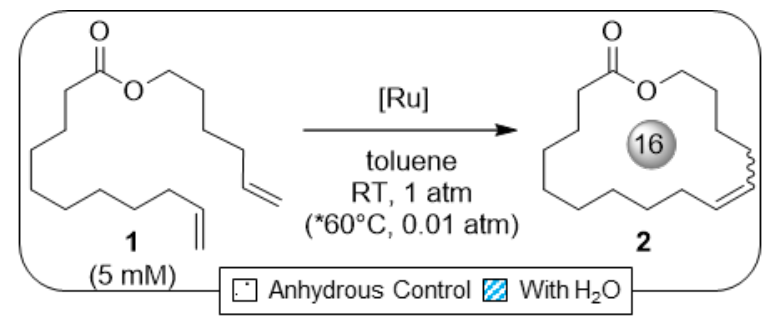

(a) Variable proportions $\mathrm{H}_{2} \mathrm{O}$ (b) $0.1 \% \mathrm{H}_{2} \mathrm{O}$; various catalysts (0.05 mol\% Ru-1)

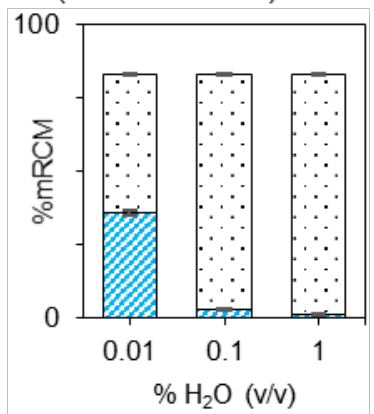
$0.05 \mathrm{~mol} \% \mathrm{Ru}: 5: 0.5$

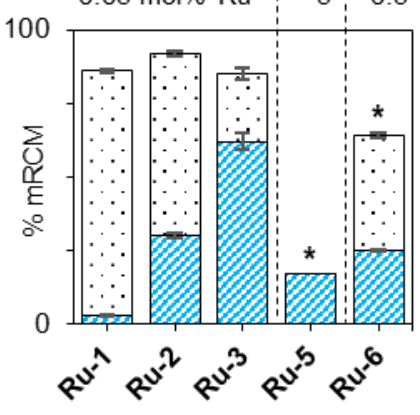

Figure 1. Impact of water on mRCM. (a) For Ru-1 at 0.5 h. (b) For various catalysts at 2 h (except Ru-6: 24 h). * Ru5, Ru-6: $60{ }^{\circ} \mathrm{C}, 0.01$ atm. ${ }^{33}$ For tabulated data, see Table S1.

Strikingly, however, water significantly accelerated positional isomerization in the self-metathesis of allylbenzene 3 (Figure 2a). Terminal phenylpropenes are notoriously susceptible to isomerization to the conjugated $\beta$ methylstyrenes. ${ }^{16 c}$ For Ru-6, 8\% isomerization was observed for the anhydrous reaction, vs $75 \%$ with $1 \% \mathrm{H}_{2} \mathrm{O}$ present. In comparison, Ru-3 showed more isomerization in the anhydrous reaction, but added water affected primarily conversions.

A second, more demanding intermolecular metathesis reaction was also examined. In the cross-metathesis of anethole 6 with methyl acrylate 7 (Figure 2b), a ca. 30\% drop in productivity was observed for $\mathbf{R u - 3}$ in the presence of $1 \%$ water.

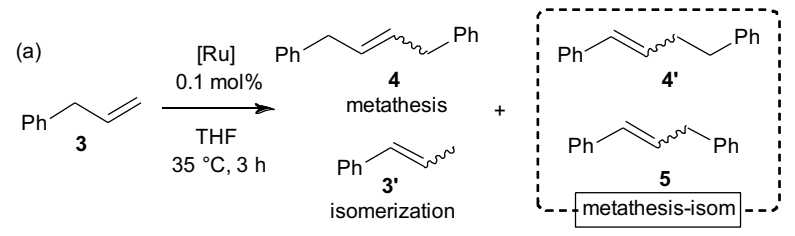

(b)

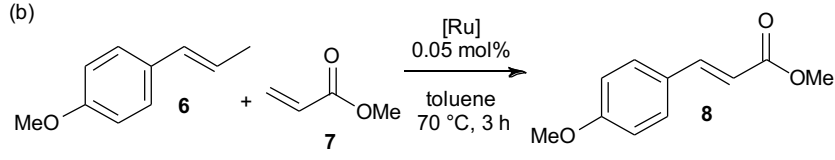

\begin{tabular}{llllll}
\hline rx & cat & $\% \mathrm{H}_{2} \mathrm{O}$ & $\begin{array}{l}\% \\
\text { conv }\end{array}$ & yield $^{a}(\% \mathrm{Z})$ & $\begin{array}{l}\% \\
\text { isom }\end{array}$ \\
\hline (a) & Ru-6 & 0 & 69 & $61(>95)$ & 8 \\
& Ru-6 & 0.1 & 57 & $47(>95)$ & 10 \\
& Ru-6 & 1 & 77 & $2(>95)$ & 75 \\
& Ru-3 & 0 & 80 & $39(23)$ & 41 \\
& Ru-3 & 1 & 61 & $27(22)$ & 34 \\
\hline
\end{tabular}

\begin{tabular}{llllll}
\hline$(b)^{b}$ & $\mathbf{R u}-3$ & 0 & 73 & $73(0)^{c}$ & - \\
& $\mathbf{R u}-3$ & 1 & 51 & $50(0)^{c}$ & - \\
\hline
\end{tabular}

${ }^{a}$ Yield of $\mathbf{4}$ (self-metathesis) or $\mathbf{8}$ (cross-metathesis). ${ }^{b} \mathbf{R u}$ 6 is omitted, as it showed no reaction. ' Solely $E-8$ is formed.

Figure 2. Impact of $\mathrm{H}_{2} \mathrm{O}$ on: (a) self-metathesis of alIylbenzene. (b) cross-metathesis of estragole and methyl acrylate.

To assess whether the negative impact of water is limited to relatively challenging reactions, we turned to RCM of diethyl diallylmalonate $\mathbf{9}$ (Figure 3). Diene $\mathbf{9}$ sets a notoriously low bar for olefin metathesis activity: the extreme facility with which it undergoes RCM makes it a correspondingly aggressive test for the impact of water. Here, in addition to the catalysts examined above, we include benzylidene, indenylidene, NHC and CAAC catalysts. ${ }^{29,34-}$ ${ }^{36}$ Initial experiments were conducted at 0.005 mol\% catalyst (50 ppm vs substrate), to enable 'anhydrous' TONs in the thousands even for less active catalysts, without masking decomposition. ${ }^{37}$

Shown in Figure $3 \mathrm{a}$ are TONs at $2 \mathrm{~h}$, at which point conversions in the presence of water plateau (Fig. S1) for all but Ru-10 and Ru-7. Notwithstanding the ease of this RCM reaction, yields decreased sharply in the presence of $1 \% \mathrm{H}_{2} \mathrm{O}$ for all catalyst surveyed. TONs of only 600 or 1800 , respectively, were observed for Ru-1 and Ru-2 (vs ca. 18000 in the anhydrous control reaction). lodide complex Ru-3 gave maximum TONs (9 800). For $\mathbf{R u - 4 , ~ a ~}$ top-performing catalyst under anhydrous conditions, TONs dropped by 60\% (from nearly 19000 to 8000 ).

Given the high susceptibility of Ru-4 to bimolecular decomposition, ${ }^{14 b}$ its performance relative to $\mathbf{R u - 3}$ was reevaluated at a catalyst loading 5-fold lower (Figure 3b). TONs in the anhydrous control reaction increased in both cases: by nearly $4 x$ for $\mathbf{R u - 4 , ~ a n d ~} 2.5 x$ for Ru-3. Clearly, bimolecular coupling occurs for both catalysts, even at 10 $\mu \mathrm{M}$ Ru. Higher water-sensitivity is evident at the lower catalyst loading: that is, decomposition by water competes more strongly with bimolecular decomposition as catalyst concentrations decline. $\mathbf{R u - 3}$ remains most productive (TON 21 000, vs 14000 for Ru-4).

In Figure 3c, we assess catalyst water-tolerance independent of metathesis activity, by normalizing TONs in the presence of water to those under anhydrous conditions. For added context, water-tolerance is plotted against TONs in the presence of water: best performance is thus high on both axes. Least tolerant are the fast-initiating catalysts $\mathbf{R u - 1}$ and $\mathbf{R u - 2}$ (3\% and 10\%, respectively), suggesting that increased time in the active cycle increases vulnerability. Consistent with this analysis is the improved tolerance (27-44\%) of the catalysts highlighted in the blue band in Figure $3 b$, none of which are fast-initating. ${ }^{38,39}$ Most robust is iodide catalyst $\mathbf{R u - 3}$ 
( $56 \%$ tolerance). Slow initiation ${ }^{40}$ is again a plausible contributor, in addition to the bulk and poor $\mathrm{H}$-bonding capacity of the iodide ligands. ${ }^{29,34,35}$

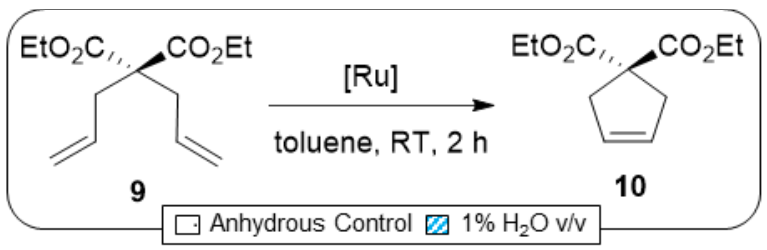

(a) $0.005 \mathrm{~mol} \% \mathrm{Ru}$

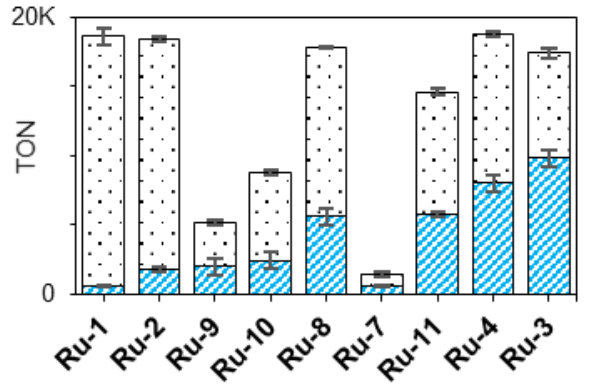

(b) $0.001 \mathrm{~mol} \% \mathrm{Ru}$

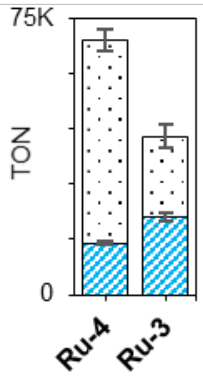

(c)

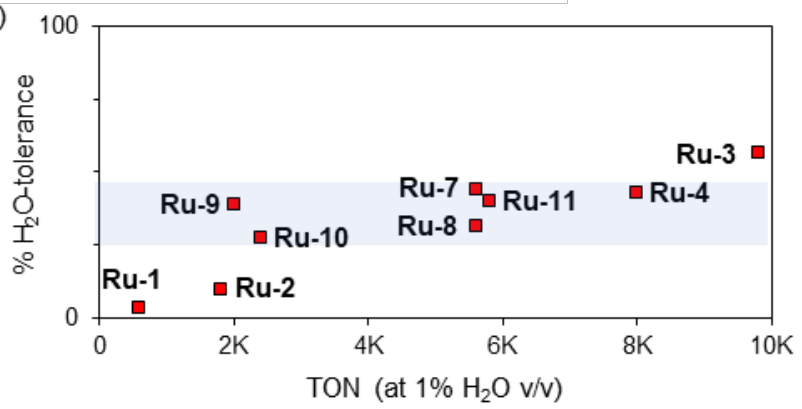

Figure 3. (a) Impact of $\mathrm{H}_{2} \mathrm{O}$ on $\mathrm{RCM}$ of 9. (b) Plot of catalyst water-tolerance, $100-\left[\left(\Delta \mathrm{TON} / \mathrm{TON}_{\text {anhyd }}\right) \times 100\right]$, vs TON (0.005 mol\% Ru). Blue band signifies intermediate tolerance. For rate curves and tabulated data, see SI.

The discussion above focuses on the impact of water on the catalyst. Given evidence for $\mathrm{H}$-bonding of water to macrolactones, however, ${ }^{41}$ we queried whether $\mathrm{H}$-bonding to the substrate might alter preferred diene conformations, and hence the thermodynamics and/or kinetics of cyclization. To probe this point, we undertook a computational study of the impact of one $\mathrm{H}$-bonded water molecule on the preferred conformations of $\mathbf{1}$ and $\mathbf{9}$. The 1:1 ratio corresponds to $0.01 \% \mathrm{v} / \mathrm{v} \mathrm{H}_{2} \mathrm{O}$ and $0.05 \mathrm{~mol} \%$ $\mathrm{Ru}$ (Figure 1a). The highly precise ANAKIN-ME neuralnetwork force field ${ }^{42,43}$ was used for extensive screening of possible geometries; calculated electronic energies for the most relevant conformers were refined using singlepoint energy calculations at the DLPNO-CCSD(T)/CBS level of theory.

Reaction free energies for RCM of $\mathbf{1}$ and $\mathbf{9}$ (see $\mathrm{SI}$ ), showed no clear change due to bound water, indicating that the negative effect is not thermodynamic in origin. The impact of water on pre-organization was therefore examined. In the absence of water, the most stable conformer for diene $\mathbf{1}$ is essentially linear, with an end-to- end distance of $>12 \AA$. In comparison, a distance of 3.72 $\AA$ is calculated for the most stable conformer of $\mathbf{9}$. Seen for the latter, but absent for $\mathbf{1}$, is a stabilizing $\pi$-stacking interaction between the two $\mathrm{C}=\mathrm{C}$ bonds, a previously overlooked contributor to the facile RCM of 9. As expected, bringing the two $\mathrm{C}=\mathrm{C}$ bonds of 9 into proximity incurs no penalty $(\Delta G=0.0 \mathrm{kcal} / \mathrm{mol}$ : Figure $4 \mathrm{a})$. For 1 , the cost is higher $(5.8 \mathrm{kcal} / \mathrm{mol})$, consistent with the lower RCM reactivity of 1 .

The impact of $\mathrm{H}$-bonded water on cyclization is shown in Figure $\mathbf{4 b}$. For both $\mathbf{1}$ and $\mathbf{9}$, the diene conformation most favourable to cyclization is predicted to be less accessible in the presence of even one molecule of water, with a negative impact on the cyclization kinetics. Macrocyclization of $\mathbf{1}$ is impeded by location of the water molecule in the middle of the nascent cycle. For $\mathbf{9}$, the water molecule is outside the forming ring, but nevertheless stabilizes the linear conformation. Indeed, water destabilizes the pre-cyclic conformation even more strongly for $\mathbf{9}$ than for 1 (by 5.6 or $2.7 \mathrm{kcal} / \mathrm{mol}$, respectively: Figure $4 b),{ }^{44}$ in part by disrupting the $C=C \pi$-stacking arrangement seen for anhydrous 9.

The unexpectedly greater negative impact of $\mathrm{H}_{2} \mathrm{O}$ on cyclization of $\mathbf{9}$ is supported by experiment. On repeating the RCM of 9 at the $5 \mathrm{mM}$ diene concentration employed in $\mathrm{mRCM}$, using the most robust catalyst Ru-3, we observe lower catalyst water-tolerance for 9 than 1 (30\% vs $73 \%$; Figure S3). Water thus has a greater negative impact on 9 than 1. By retarding the rate of metathesis relative to catalyst decomposition, therefore, $\mathrm{H}$-bonded water can exacerbate catalyst decomposition, further limiting RCM performance in the presence of water.

(a)

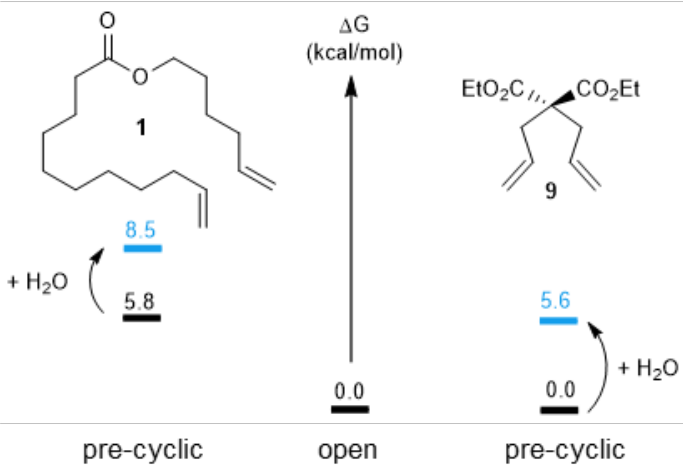

(b)
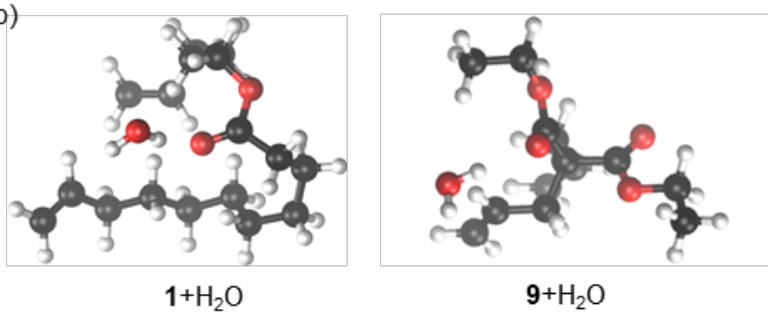
Figure 4. (a) Impact of $1 \mathrm{H}_{2} \mathrm{O}$ on the free energies required to adopt the incipient ("pre-cyclic") conformation for 1 and 9. (b) Destabilization of pre-cyclic conformations by $\mathrm{H}$-bonded water. C..C distances: $3.72 \AA$ (1); $4.21 \AA$ (9).

The foregoing demonstrates that even low levels of water severely degrade the productivity of leading ruthenium catalysts for olefin metathesis. This is an important clue to the pathways by which water triggers decomposition: it points toward direct attack by water on the catalyst, independent of any effects arising from water as a medium. Fast-initiating catalysts prove particularly vulnerable. Maximum productivity is seen for slower-initiating, bulkier iodide and CAAC catalysts, which emerge as the systems of choice where drying is impractical, or water is an essential co-solvent. These findings represent the first insights into structure-decomposition relationships for olefin metathesis in the presence of water. They will aid in deconvoluting the mechanisms by which water causes decomposition, and ultimately, design of truly water-tolerant olefin metathesis catalysts.

\section{ASSOCIATED CONTENT}

The Supporting Information is available free of charge on the ACS Publications website.

PDF file: experimental and computational details, numerical data for Figs. 1-4

xyz files: computed xyz coordinates and energies

\section{AUTHOR INFORMATION}

\section{Corresponding Authors}

*dfogg@uottawa.ca,dfo025@uib.no; carine.michel@enslyon.fr

\section{ACKNOWLEDGMENT}

This work was funded by the Natural Sciences and Engineering Research Council of Canada (NSERC), the Research Council of Norway (RCN, project 288135), and Centre National de la Recherche Scientifique: SYSPROD and AXELERA Pôle de Compétitivité (PSMN Data Center). The University of Ottawa, CNRS, and ENS Lyon are thanked for support via the International Associated Laboratory 'Fundamental Catalysis for Green Chemistry' (FUNCAT). Apeiron is thanked for gifts of CAAC catalysts. Dedicated to P. H. Dixneuf, in honour of his outstanding contributions to organometallic chemistry and catalysis.

\section{REFERENCES}

(1) (a) Grela, K., Olefin Metathesis-Theory and Practice. Wiley: Hoboken, NJ, 2014. (b) Grubbs, R. H.; Wenzel, A. G., Handbook of Metathesis. 2nd ed.; Wiley-VCH: Weinheim, 2015.

(2) (a) Cossy, J.; Arseniyadis, S.; Meyer, C., Metathesis in Natural Product Synthesis: Strategies, Substrates and Catalysts. WileyVCH: Weinheim, 2010. (b) Furstner, A., Metathesis in Total Synthesis.
Chem. Commun. 2011, 47, 6505-6511. (c) Tyagi, M. B., Fabio; Poongavanam, Vasanthanathan, Drug Syntheses Beyond the Rule of 5. Chem - Eur. J. 2020, 26, 49-88. (d) Fürstner, A., Catalysis for Total Synthesis: A Personal Account. Angew. Chem., Int. Ed. 2014, 53, 85878598.

(3) For recent reviews, see: (a) Isenegger, P. G.; Davis, B. G., Concepts of Catalysis in Site-Selective Protein Modifications. J. Am. Chem. Soc. 2019, 141, 8005-8013. (b) Vinogradova, E. V., Organometallic Chemical Biology: An Organometallic Approach to Bioconjugation. Pure Appl. Chem. 2017, 89, 1619-1640. (c) Messina, M. S.; Maynard, H. D., Modification of Proteins using Olefin Metathesis. Mater. Chem. Front. 2020, 4, 1040-1051.

(4) For selected recent examples of metathesis in chemical biology, see: (a) Bhushan, B.; Lin, Y. A.; Bak, M.; Phanumartwiwath, A.; Yang, N.; Bilyard, M. K.; Tanaka, T.; Hudson, K. L.; Lercher, L.; Stegmann, M.; Mohammed, S.; Davis, B. G., Genetic Incorporation of Olefin Cross-Metathesis Reaction Tags for Protein Modification. J. Am. Chem. Soc. 2018, 140, 14599-14603. (b) Lu, X.; Fan, L.; Phelps, C. B.; Davie, C. P.; Donahue, C. P., Ruthenium Promoted On-DNA RingClosing Metathesis and Cross-Metathesis. Bioconjugate Chem. 2017, 28, 1625-1629. (c) Grison, C. M.; Burslem, G. M.; Miles, J. A.; Pilsl, L. K. A.; Yeo, D. J.; Imani, Z.; Warriner, S. L.; Webb, M. E.; Wilson, A. J., Double Quick, Double Click Reversible Peptide "Stapling". Chem. Sci. 2017, 8, 5166-5171. (d) Cromm, P. M.; Spiegel, J.; Kuchler, P.; Dietrich, L.; Kriegesmann, J.; Wendt, M.; Goody, R. S.; Waldmann, H.; Grossmann, T. N., Protease-Resistant and Cell-Permeable DoubleStapled Peptides Targeting the Rab8a GTPase. ACS Chem. Biol. 2016, $11,2375-2382$

(5) (a) Sabatino, V.; Ward, T. R., Aqueous Olefin Metathesis: Recent Developments and Applications. Beilstein J. Org. Chem. 2019, 15, 445-468. (b) Levin, E.; Ivry, E.; Diesendruck, C. E.; Lemcoff, N. G., Water in N-Heterocyclic Carbene-Assisted Catalysis. Chem. Rev. 2015, 115, 4607-4692. (c) Lipshutz, B. H., Ghorai, S., Olefin Metathesis in Water and Aqueous Media. In Olefin Metathesis - Theory and Practice, Grela, K., Ed. 2014; pp 515-521. (d) Grela, K.; Gulajski, L.; Skowerski, K., Alkene Metathesis in Water. In Metal-Catalyzed Reactions in Water, Dixneuf, P. H.; Cadierno, V., Eds. Wiley-VCH: Weinheim, 2013; pp 291-336.

(6) The last two years alone have seen spectacular advances in the applications of ring-opening metathesis polymerization (ROMP). Selected examples: (a) Church, D. C.; Pokorski, J. K., Cell Engineering with Functional Poly(oxanorbornene) Block Copolymers. Angew. Chem., Int. Ed. 2020, 59, 11379-11383. (b) Foster, J. C.; Grocott, M. C.; Arkinstall, L. A.; Varlas, S.; Redding, M. J.; Grayson, S. M.; O'Reilly, R. K., It is Better with Salt: Aqueous Ring-Opening Metathesis Polymerization at Neutral pH. J. Am. Chem. Soc. 2020, 142, 1387813885. (c) Church, D. C.; Takiguchi, L.; Pokorski, J. K., Optimization of Ring-Opening Metathesis Polymerization (ROMP) under Physiologically Relevant Conditions. Polym. Chem. 2020, 11, 44924499. (d) Varlas, S.; Foster, J. C.; O’Reilly, R. K., Ring-opening metathesis polymerization-induced self-assembly (ROMPISA). Chem. Commun. 2019, 55, 9066-9071. (e) Varlas, S.; Keogh, R.; Xie, Y.; Horswell, S. L.; Foster, J. C.; O’Reilly, R. K., Polymerization-Induced Polymersome Fusion. J. Am. Chem. Soc. 2019, 141, 20234-20248. (f) Feist, J. D.; Xia, Y., Enol Ethers Are Effective Monomers for RingOpening Metathesis Polymerization: Synthesis of Degradable and Depolymerizable Poly(2,3-dihydrofuran). J. Am. Chem. Soc. 2020, 142, 1186-1189. (g) Sui, X. L.; Zhang, T. Q.; Pabarue, A. B.; Fu, L. B.; Gutekunst, W. R., Alternating Cascade Metathesis Polymerization of Enynes and Cyclic Enol Ethers with Active Ruthenium Fischer Carbenes. J. Am. Chem. Soc. 2020, 142, 12942-12947. (h) Song, J. A. Peterson, G. I.; Bang, K. T.; Ahmed, T. S.; Sung, J. C.; Grubbs, R. H.; Choi, T. L., Ru-Catalyzed, cis-Selective Living Ring-Opening Metathesis Polymerization of Various Monomers, Including a Dendronized Macromonomer, and Implications to Enhanced Shear Stability. J. Am. Chem. Soc. 2020, 142, 10438-10445. (i) Hsu, T. W.; Kim, C.; Michaudel, Q., Stereoretentive Ring-Opening Metathesis Polymerization to 
Access All-cis Poly(p-phenylenevinylene)s with Living Characteristics. J. Am. Chem. Soc 2020, 142, 11983-11987. (j) Yasir, M.; Liu, P.; Tennie, I. K.; Kilbinger, A. F. M., Catalytic living ring-opening metathesis polymerization with Grubbs' second- and third-generation catalysts. Nature Chem. 2019, 11, 488-494. (k) Debsharma, T.; Behrendt, F. N.; Laschewsky, A.; Schlaad, H., Ring-Opening Metathesis Polymerization of Biomass-Derived Levoglucosenol. Angew. Chem., Int. Ed. 2019, 58, 6718-6721. (I) Jung, K.; Ahmed, T. S.; Lee, J.; Sung, J. C.; Keum, H.; Grubbs, R. H.; Choi, T. L., Living beta-selective cyclopolymerization using Ru dithiolate catalysts. Chem. Sci. 2019, 10, 8955-8963. (m) Theunissen, C.; Ashley, M. A.; Rovis, T., Visible-Light-Controlled Ruthenium-Catalyzed Olefin Metathesis. J. Am. Chem. Soc. 2019, 141, 6791-6796. (n) Song, K.; Kim, K.; Hong, D.; Kim, J.; Heo, C. E.; Kim, H. I.; Hong, S. H., Highly Active Ruthenium Metathesis Catalysts Enabling Ring-Opening Metathesis Polymerization of Cyclopentadiene at Low Temperatures. Nature Commun. 2019, 10, 3860.

(7) (a) Higman, C. S.; Lummiss, J. A. M.; Fogg, D. E. Olefin Metathesis at the Dawn of Uptake in Pharmaceutical and Specialty Chemicals Manufacturing. Angew. Chem., Int. Ed. 2016, 55, 35523565. (b) Yu, M.; Lou, S.; Gonzalez-Bobes, F., Ring-Closing Metathesis in Pharmaceutical Development: Fundamentals, Applications, and Future Directions. Org. Process Res. Dev. 2018, 22, 918-946. (c) Farina, V.; Horváth, A., Ring-Closing Metathesis in the Large-Scale Synthesis of Pharmaceuticals. In Handbook of Metathesis, Grubbs, R. H.; Wenzel, A. G., Eds. Wiley-VCH: Weinheim, 2015; Vol. 2, pp 633-658. (d) Fandrick, K. R.; Savoie, J.; Jinhua, N. Y.; Song, J. J.; Senanayake, C. $\mathrm{H}$., Challenges and Opportunities for Scaling the Ring-Closing Metathesis Reaction in the Pharmaceutical Industry. In Olefin Metathesis - Theory and Practice, Grela, K., Ed. Wiley: Hoboken, 2014; pp 349-366. For a recent example of an oncology drug candidate, see: (e) St-Pierre, G.; Cherney, A. H.; Chen, W.; Dong, X.; Dornan, P. K.; Griffin, D. J.; Houk, K. N.; Lin, J. B.; Osgood, S.; Elipe, M. V. S.; Timmons, H. C.; Xie, Y.; Tedrow, J. S.; Thiel, O. R.; Smith, A. G., Accelerated Development of a Scalable Ring-Closing Metathesis to Manufacture AMG 176 Using a Combined High-Throughput Experimentation and Computational Modeling Approach. Org. Proc. Res. Dev. 2020, ASAP article.

(8) Masuda, S.; Tsuda, S.; Yoshiya, T., Ring-closing metathesis of unprotected peptides in water. Org. Biomol. Chem. 2018, 16, 93649367.

(9) Monty, O. B. C.; Nyshadham, P.; Bohren, K. M.; Palaniappan, M.; Matzuk, M. M.; Young, D. W.; Simmons, N., Homogeneous and Functional Group Tolerant Ring-Closing Metathesis for DNA-Encoded Chemical Libraries. Acs Combinatorial Science 2020, 22, 80-88.

(10) Lawrenson, S. B.; Arkinstall, L. A.; O'Reilly, R. K.; Foster, J. C., Self-assembled nanostructures from amphiphilic block copolymers prepared via ring-opening metathesis polymerization (ROMP). Prog. Polym. Sci. 2020, 107, 101278-101318.

(11) Foster, J. C.; Varlas, S.; Blackman, L. D.; Arkinstall, L. A.; O'Reilly, R. K., Ring-Opening Metathesis Polymerization in Aqueous Media Using a Macroinitiator Approach. Angew. Chem., Int. Ed. 2018, 57, 10672-10676.

(12) For a similar perspective in the context of ROMP, and the consequent advantages associated with high-strain monomers, see: Camm, K. D.; Fogg, D. E., From Drug Cocktails to Tissue Engineering: Synthesis of ROMP Polymers for Biological Applications. In NATO Sci. Ser. II, Imamoglu, Y.; Dragutan, V., Eds. Springer Verlag: Berlin, 2007; Vol. 243, pp 285-303.

(13) The breakthrough discovery that a chalcogen relay (S-allyl or Se-allyl cysteine) can greatly accelerate metathesis relative to decomposition opened the door to site-selective protein modification. See refs 3a and: (a) Lin, Y. A.; Chalker, J. M.; Floyd, N.; Bernardes, G. J. L.; Davis, B. G., Allyl Sulfides Are Privileged Substrates in Aqueous Cross-Metathesis: Application to Site-Selective Protein Modification. J. Am. Chem. Soc. 2008, 130, 9642-9643. (b) Lin, Y. A.; Davis, B. G., The Allylic Chalcogen Effect in Olefin Metathesis. Beilstein J. Org. Chem. 2010, 6, 1219-1228. Superstoichiometric Ru is essential, however (for example, 100 equiv in ref $b$ ). Davis makes cogent arguments for this sacrifice in light of the strategic importance of the modified protein target (ref 3a). Nevertheless, Vinogravoda notes that protected peptides and solid-phase synthesis are widely employed in olefin metathesis of peptidic substrates, to circumvent decomposition. See: ref $3 b$.

(14) Bimolecular decomposition of the four-coordinate intermediates $\operatorname{RuCl}_{2}(\mathrm{~L})\left(=\mathrm{CH}_{2}\right)$ has now been established for phosphine, NHC, and CAAC derivatives. See: (a) Bailey, G. A.; Foscato, M.; Higman, C. S.; Day, C. S.; Jensen, V. R.; Fogg, D. E., Bimolecular Coupling as a Vector for Decomposition of Fast-Initiating Olefin Metathesis Catalysts. J. Am. Chem. Soc. 2018, 140, 6931-6944. (b) Nascimento, D. L.; Fogg, D. E., Origin of the Breakthrough Productivity of RutheniumCAAC Catalysts in Olefin Metathesis (CAAC = Cyclic Alkyl Amino Carbene). J. Am. Chem. Soc. 2019, 141, 19236-19240. (c) Nascimento, D. L.; Gawin, A.; Gawin, R.; Guńka, P. A.; Zachara, J.; Skowerski, K.; Fogg, D. E., Integrating Activity with Accessibility in Olefin Metathesis: An Unprecedentedly Reactive Ruthenium-Indenylidene Catalyst Bearing a Cyclic Alkyl Amino Carbene. J. Am. Chem. Soc. 2019, 141, 10626-10631. (d) Thiel, V.; Wannowius, K.-J.; Wolff, C.; Thiele, C. M.; Plenio, $\mathrm{H}$., Ring-Closing Metathesis Reactions: Interpretation of Conversion-Time Data. Chem. - Eur. J. 2013, 19, 16403-16414. (e) Schrodi, Y., Mechanisms of Olefin Metathesis Catalyst Decomposition and Methods of Catalyst Reactivation. In Handbook of Metathesis, Grubbs, R. H.; Wenzel, A. G., Eds. Wiley-VCH: Weinheim, 2015; pp 323-342. Of keen relevance to metathesis in basic water, bimolecular coupling contributes to complete inactivation of hydroxide derivative $\mathrm{Ru}(\mathrm{OH})_{2}(\mathrm{~L})\left(=\mathrm{CH}_{2}\right)$. See: (f) Goudreault, A. Y.; Walden, D. M.; Nascimento, D. L.; Botti, A. G.; Steinmann, S. N.; Michel, C.; Fogg, D. E., Hydroxide-Induced Degradation of Olefin Metathesis Catalysts: A Challenge for Metathesis in Alkaline Media. ACS Catal. 2020, 10, 3838-3843.

(15) Lu, X.; Fan, L.; Phelps, C. B.; Davie, C. P.; Donahue, C. P., Ruthenium Promoted On-DNA Ring-Closing Metathesis and CrossMetathesis. Bioconjugate Chem. 2017, 28, 1625-1629.

(16) For an overview of these challenges, and examples of unintended $\mathrm{C}=\mathrm{C}$ positional isomerism, see: (a) van Lierop, B. J.; Lummiss, J. A. M.; Fogg, D. E., Ring-Closing Metathesis. In Olefin Metathesis-Theory and Practice, Grela, K., Ed. Wiley: Hoboken, NJ, 2014; pp 85-152. For studies identifying some of the Ru species responsible, and excluding some commonly-proposed candidates, see: (b) Higman, C. S.; Lanterna, A. E.; Marin, M. L.; Scaiano, J. C.; Fogg, D. E., Catalyst Decomposition During Olefin Metathesis Yields Isomerization-Active Ru Nanoparticles. ChemCatChem 2016, 8, 24462449. (c) Higman, C. S.; Plais, L.; Fogg, D. E., Isomerization During Olefin Metathesis: An Assessment of Potential Catalyst Culprits. ChemCatChem 2013, 5, 3548-3551.

(17) For a recent study of the negative impact of water on Hoveyda-class catalysts (including Ru-8 and water-soluble variants), and a potential solution, see: (a) Jongkind, L. J.; Rahimi, M.; Poole, D.; Ton, S. J.; Fogg, D. E.; Reek, J. N. H., Protection of Ruthenium Olefin Metathesis Catalysts by Encapsulation in a Self-assembled Resorcinarene Capsule. ChemCatChem 2020, 12, 4019-4023. For the mechanism by which water decomposes the second-generation Grubbs catalyst Ru-11 and other $\mathrm{PC}_{3}$-stabilized catalysts, see: (b) McClennan, W. L.; Rufh, S. A.; Lummiss, J. A. M.; Fogg, D. E., A General Decomposition Pathway for Phosphine-Stabilized Metathesis Catalysts: Lewis Donors Accelerate Methylidene Abstraction. J. Am. Chem. Soc. 2016, 138, 14668-14677. For the slower decomposition of the first-generation Grubbs catalyst by this pathway, see: (c) Lummiss, J. A. M.; McClennan, W. L.; McDonald, R.; Fogg, D. E., Donor-Induced Decomposition of the Grubbs Catalysts: An Intercepted Intermediate Organometallics 2014, 33, 6738-6741. For studies showing quenching of metathesis by hydroxide ion via formation of inactive $\mathrm{Ru}-\mathrm{OH}$ species, see ref $14 f$ and: (d) Santos, A. G.; Bailey, G. A.; dos Santos, E. N.; Fogg, D. E., Overcoming Catalyst Decomposition in Acrylate Metathesis: Poly-phenol Resins as Enabling Agents for Phosphine- 
Stabilized Metathesis Catalysts. ACS Catal. 2017, 7, 3181-3189. Recent work reveals that added $\mathrm{HCl}$ improves the performance of related Ru catalysts even at neutral $\mathrm{pH}$ : reversal of $\mathrm{Ru}-\mathrm{OH}$ formation was proposed. See: ref $6 \mathrm{~b}$.

(18) For an early review noting that water is not an innocuous medium for Ru-promoted ROMP chemistry, and that success is determined by the kinetics of polymerization vs catalyst decomposition, see ref 12 . For other early reports of the negative effect of water in Ru-catalyzed olefin metathesis, see: (a) Kim, M.; Eum, M. S.; Jin, M. Y.; Jun, K. W.; Lee, C. W.; Kuen, K. A.; Kim, C. H.; Chin, C. S., Reactions of Ruthenium Benzylidenes with $\mathrm{H}_{2} \mathrm{O}$ to give Benzaldehyde and (Aqua)ruthenium complex. J. Organomet. Chem. 2004, 689, 3535-3540. (b) Dinger, M. B.; Mol, J. C., Degradation of the First-Generation Grubbs Metathesis Catalyst with Primary Alcohols, Water, and Oxygen. Formation and Catalytic Activity of Ruthenium(II) Monocarbonyl Species. Organometallics 2003, 22, 1089-1095.

(19) The limiting solubility of water in toluene is reported as $0.05 \%$ v/v. See: Kirchnerová, J.; Cave, C. B. G., The Solubility of Water in Low-Dielectric Solvents. Can. J. Chem. 1976, 54, 3909-3916.

(20) See ref 7a and: (a) Morse, J. S.; Lalonde, T.; Xu, S.; Liu, W. R., Learning from the Past: Possible Urgent Prevention and Treatment Options for Severe Acute Respiratory Infections Caused by 2019-nCoV. ChemBioChem 2020, 21, 730-738. (b) Schwartz, A. D.; Graham, L. A., Potential Maternal and Infant Outcomes from Coronavirus 2019-nCoV (SARS-CoV-2) Infecting Pregnant Women: Lessons from SARS, MERS, and Other Human Coronavirus Infections. Viruses 2020, 12, 194. (c) Cink, R. D.; Lukin, K. A.; Bishop, R. D.; Zhao, G.; Pelc, M. J.; Towne, T. B.; Gates, B. D.; Ravn, M. M.; Hill, D. R.; Ding, C.; Cullen, S. C.; Mei, J. Z.; Leanna, M. R.; Henle, J.; Napolitano, J. G.; Nere, N. K.; Chen, S.; Sheikh, A.; Kallemeyn, J. M., Development of the Enabling Route for Glecaprevir via Ring-Closing Metathesis. Org. Proc. Res. Dev. 2020, 24, 183-200. (d) Caspi, D. D.; Cink, R. D.; Clyne, D.; Diwan, M.; Engstrom, K. M.; Grieme, T.; Mei, J. Z.; Miller, R. W.; Mitchell, C.; Napolitano, J. G.; Nere, N.; Ravn, M. M.; Sheikh, A.; Wagaw, S.; Zhang, H. Q., Process Development of ABT-450. A First Generation NS3/4A Protease Inhibitor for HC. Tetrahedron 2019, 75, 4271-4286. (e) Horvath, A.; Depre, D.; Vermeulen, W. A. A.; Wuyts, S. L.; Harutyunyan, S. R.; Binot, G.; Cuypers, J.; Couck, W.; Van den Heuvel, D., Ring-Closing Metathesis on Commercial Scale: Synthesis of HCV Protease Inhibitor Simeprevir. J. Org. Chem. 2019, 84, 4932-4939.

(21) Higman, C. S.; Nascimento, D.; Ireland, B. J.; Audorsch, S.; Bailey, G. A.; Fogg, D. E., Chelate-Assisted Ring-Closing Metathesis: A Strategy for Accelerating Macrocyclization at Ambient Temperatures. J. Am. Chem. Soc. 2018, 140, 1604-1607.

(22) Water content is typically $<5 \mathrm{ppm}$, as indicated by regular Karl-Fischer titration.

(23) Kraft, P., Aroma Chemicals IV: Musks. In Chemistry and Technology of Flavors and Fragrances, Rowe, D. J., Ed. CRC Press: Boca Raton, 2005; pp 143-168.

(24) (a) Conrad, J. C.; Eelman, M. D.; Duarte Silva, J. A.; Monfette, S.; Parnas, H. H.; Snelgrove, J. L.; Fogg, D. E., Oligomers as Intermediates in Ring-Closing Metathesis. J. Am. Chem. Soc. 2007, 129, 1024-1025. (b) Monfette, S.; Fogg, D. E., Equilibrium Ring-Closing Metathesis. Chem. Rev. 2009, 109, 3783-3816.

(25) Higher concentrations can be tolerated where partial rigidity creates a conformational bias toward cyclization. In the production of peptidomimetic macrocycles as drug candidates for the treatment of Hepatitis $C$, the substrate concentrations at which $\mathrm{mRCM}$ could be achieved ranged from 2,4 mM for Idenex's IDX320, to a remarkable $0.2 \mathrm{M}$ (for Boehringer-Ingelheim's Ciluprevir). See: ref 7a. The latter was due to a conformational bias toward cyclization, reinforced by the serendipitous sensitivity of the effective molarity to protection of a key amide site.

(26) (a) Fürstner, A.; Langemann, K., Conformationally Unbiased Macrocyclization Reactions by Ring Closing Metathesis. J. Org. Chem. 1996, 61, 3942-3943. (b) Fürstner, A.; Langemann, K., Macrocycles by Ring-Closing Metathesis. Synthesis 1997, 792-803.
(27) Even at 1 mol\% Ru-2, however, mRCM yields remained well below those of the anhydrous reaction: $73 \%$, vs $92 \%$. See Figure $\mathrm{S} 1$.

(28) For studies demonstrating that $\mathrm{O}_{2}$ is less detrimental than air, see: (a) Guidone, S.; Songis, O.; Nahra, F.; Cazin, C. S. J., Conducting Olefin Metathesis Reactions in Air: Breaking the Paradigm. ACS Catal. 2015, 5, 2697-2701. (b) Ton, S. J.; Fogg, D. E., The Impact of Oxygen on Leading and Emerging Ru-Carbene Catalysts for Olefin Metathesis: An Unanticipated Correlation Between Robustness and Metathesis Activity ACS Catal. 2019, 9, 11329-11334.

(29) Tracz, A.; Matczak, M.; Katarzyna; Urbaniak; Skowerski, K., Nitro-Grela-Type Complexes Containing lodides - Robust and Selective Catalysts for Olefin Metathesis Under Challenging Conditions. Beilstein J. Org. Chem. 2015, 11, 1823-1832.

(30) Hoveyda, A. H.; Lombardi, P. J.; O'Brien, R. V.; Zhugralin, A. R., H-Bonding as a Control Element in Stereoselective Ru-Catalyzed Olefin Metathesis. J. Am. Chem. Soc. 2009, 131, 8378-8379.

(31) Torker, S.; Khan, R. K. M.; Hoveyda, A. H., The Influence of Anionic Ligands on Stereoisomerism of $\mathrm{Ru}$ Carbenes and Their Importance to Efficiency and Selectivity of Catalytic Olefin Metathesis Reactions. J. Am. Chem. Soc. 2014, 136, 3439-3455.

(32) For the slow initiation of Ru metathesis catalysts containing cis-chelating pseudohalide ligands, see: Monfette, S.; Camm, K. D.; Gorelsky, S. I.; Fogg, D. E., Electronic Effects of the Anionic Ligand in Ruthenium-Catalyzed Olefin Metathesis. Organometallics 2009, 28, 944-946.

(33) A slight vacuum was introduced to protect these lowerproductivity catalysts against ethylene-induced decomposition. For a recent overview of the problem, see: (a) Hoveyda, A. H.; Liu, Z.; Qin, C.; Koengeter, T.; Mu, Y., Impact of Ethylene on Efficiency and Stereocontrol in Olefin Metathesis: When to Add It, When to Remove It, and When to Avoid It. Angew. Chem., Int. Ed. 2020, 59, 2-27. For the detrimental effect of ethylene on mRCM of 1, see: (b) Monfette, S.; Eyholzer, M.; Roberge, D. M.; Fogg, D. E., Getting RCM Off the Bench: Reaction-Reactor Matching Transforms Metathesis Efficiency in the Assembly of Large Rings. Chem. - Eur. J. 2010, 16, 11720-11725.

(34) Abbas, M.; Slugovc, C., As Low as Reasonably Achievable Catalyst Loadings in the Cross Metathesis of Olefins with Ethyl Acrylate. Tetrahedron Lett. 2011, 52, 2560-2562.

(35) Nechmad, N. B.; Phatake, R.; Ivry, E.; Poater, A.; Lemcoff, N. G., Unprecedented Selectivity of Ruthenium lodide Benzylidenes in Olefin Metathesis Reactions. Angew. Chem., Int. Ed. 2020, 59, 35393543.

(36) Neither Z-selective catalyst reacted with 2, presumably owing to steric clashes with the homoallylic ester groups, as they react with allylbenzene and the prolactone 1 . They are therefore omitted from Figure 3.

(37) Least active is the first-generation Hoveyda catalyst Ru-7, for which TON at $2 \mathrm{~h}=600$ when water is present. The water-tolerance of Ru-7 was therefore re-assayed at $24 \mathrm{~h}$ (TON 13 300). Its watertolerance was maintained: $44 \%$, vs $42 \%$ at $2 \mathrm{~h}$.

(38) Literature evidence for slow initiation is given in Table S3. While direct comparisons are limited, the Grubbs group established that the observed rate constants for initiation of a series of CAAC catalysts was on the order of $10^{-3} \mathrm{~s}^{-1}$ and below, even at $60^{\circ} \mathrm{C}$. See (a) Engle, K. M.; Lu, G.; Luo, S.-X.; Henling, L. M.; Takase, M. K.; Liu, P.; Houk, K. N.; Grubbs, R. H., Origins of Initiation Rate Differences in Ruthenium Olefin Metathesis Catalysts Containing Chelating Benzylidenes. J. Am. Chem. Soc. 2015, 137, 5782-5792. (b) Marx, V. M.; Sullivan, A. H.; Melaimi, M.; Virgil, S. C.; Keitz, B. K.; Weinberger, D. S.; Bertrand, G.; Grubbs, R. H., Cyclic Alkyl Amino Carbene (CAAC) Ruthenium Complexes as Remarkably Active Catalysts for Ethenolysis. Angew. Chem., Int. Ed. 2015, 54, 1919-1923. For context, initiation of Ru-10 and Ru-9 was slower than Ru-4 by 225 and 900x (respectively) at RT. See: ref 14c.

(39) For the slow initiation of Ru-11 even at $80{ }^{\circ} \mathrm{C}$, see: (a) Sanford, M. S.; Love, J. A.; Grubbs, R. H., Mechanism and Activity of Ruthenium Olefin Metathesis Catalysts. J. Am. Chem. Soc. 2001, 123, 
6543-6554. Re-entry into catalysis is much slower for the resting-state methylidene species formed by Ru-11 and the indenylidene catalyst Ru-9, by 275 x in the case of Ru-11. See (b) Lummiss, J. A. M.; Higman, C. S.; Fyson, D. L.; McDonald, R.; Fogg, D. E., The Divergent Effects of Strong NHC Donation in Catalysis. Chem. Sci. 2015, 6, 6739-6746. (c) Lummiss, J. A. M.; Perras, F. A.; Bryce, D. L.; Fogg, D. E., StericallyDriven Metathesis: The Impact of Alkylidene Substitution on the Reactivity of the Grubbs Catalysts. Organometallics 2016, 35, 691698.

(40) Wappel, J.; Urbina-Blanco, C. A.; Abbas, M.; Albering, J. H.; Saf, R.; Nolan, S. P.; Slugovc, C., Halide Exchanged Hoveyda-Type Complexes in Olefin Metathesis. Beilstein J. Org. Chem. 2010, 6, 10911098.

(41) Barrett, A. G. M.; Hamprecht, D.; James, R. A.; Ohkubo, M.; Procopiou, P. A.; Toledo, M. A.; White, A. J. P.; Williams, D. J., Synthesis and Characterization of Coronanes: Multicyclopropane-Fused Macrocyclic Arrays. J. Org. Chem. 2001, 66, 2187-2196.

(42) Smith, J. S.; Isayev, O.; Roitberg, A. E., ANI-1: an extensible neural network potential with DFT accuracy at force field computational cost. Chem. Sci. 2017, 8, 3192-3203.

(43) The new neural network force field ANAKIN (ref 42) affords the best accuracy-to-cost ratio for organic molecules, with ab initioquality energies and geometries, for the reduced computational cost of classic force-field simulations.

(44) In the equilibrium between the extended conformer and its pre-cyclic form, the added water molecule favours the extended conformer by 100 -fold for $\mathbf{1}$, vs 5 orders of magnitude for diethyl diallylmalonate 9 . For anhydrous $1: \Delta \mathrm{G}=5.8 \mathrm{kcal} / \mathrm{mol}$ (i.e. $K=5.5 \times 10^{-}$ 5). With $1 \mathrm{H}_{2} \mathrm{O}: \Delta \mathrm{G}=8.5 \mathrm{kcal} / \mathrm{mol}$ (i.e. $\left.K=5.7 \times 10^{-7}\right)$. For anhydrous 9: $\Delta \mathrm{G}=0 \mathrm{kcal} / \mathrm{mol}(K=1)$. With $1 \mathrm{H}_{2} \mathrm{O}: \Delta \mathrm{G}=5.6 \mathrm{kcal} / \mathrm{mol}\left(K=8.10^{-5}\right)$. 


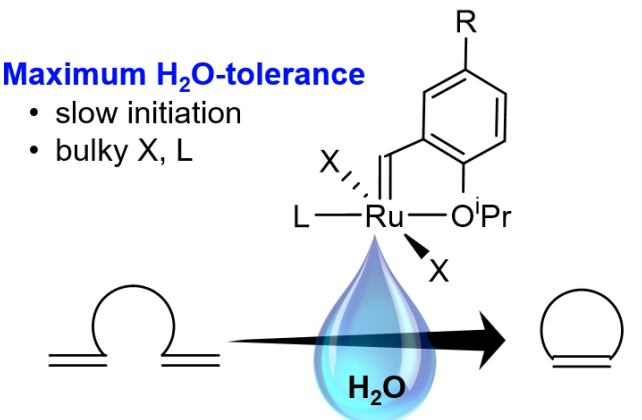

